\title{
Assessment of the Biochemical Responses of Wheat Seedlings to Soil Drought after Application of Selective Herbicide
}

\author{
Dessislava Todorova, Iskren Sergiev*(D), Zornitsa Katerova, Elena Shopova, Ljudmila Dimitrova \\ and Liliana Brankova
}

Citation: Todorova, D.; Sergiev, I.; Katerova, Z.; Shopova, E.; Dimitrova, L.; Brankova, L. Assessment of the Biochemical Responses of Wheat Seedlings to Soil Drought after Application of Selective Herbicide. Plants 2021, 10, 733. https://doi.org/ 10.3390/plants10040733

Academic Editor: Svetlana Misheva

Received: 18 March 2021

Accepted: 6 April 2021

Published: 9 April 2021

Publisher's Note: MDPI stays neutral with regard to jurisdictional claims in published maps and institutional affiliations.

Copyright: (C) 2021 by the authors. Licensee MDPI, Basel, Switzerland. This article is an open access article distributed under the terms and conditions of the Creative Commons Attribution (CC BY) license (https:// creativecommons.org/licenses/by/ $4.0 /)$.
Institute of Plant Physiology and Genetics-Bulgarian Academy of Sciences, Acad G. Bonchev Str., Bl. 21. 1113 Sofia, Bulgaria; dessita@bio21.bas.bg (D.T.); zkaterova.landzhova@gmail.com (Z.K.); kostei@abv.bg (E.S.); dim.lyudmila@gmail.com (L.D.); lbrankova@abv.bg (L.B.)

* Correspondence: iskren@bio21.bas.bg

\begin{abstract}
Drought is a major environmental constrain with a deleterious effect on plant development leading to a considerable reduction of crop productivity worldwide. Wheat is a relatively drought tolerant crop during the vegetative stage. The herbicide Serrate ${ }^{\circledR}$ (Syngenta) is a preparation containing two active chemical substances with different modes of action, which inhibit the biosynthesis of fatty and amino acids. It is commonly used as a systemic and selective chemical agent to control annual grass and broadleaf weeds in cereal crops and particularly in wheat, which is tolerant to Serrate ${ }^{\circledR}$. Seventeen-day-old wheat seedlings (Triticum aestivum L., cv. Sadovo-1) grown as soil culture under controlled conditions were sprayed with an aqueous solution of Serrate ${ }^{\circledR}$. Seventy-two hours later the plantlets were subjected to drought stress for seven days to reach a severe water deficit followed by four days of recovery with a normal irrigation regime. Oxidative stress markers, non-enzymatic, and enzymatic antioxidants were analyzed in the leaves of plants from the different treatment groups (herbicide-treated, droughts-stressed, and individuals which were consecutively subjected to both treatments) at 0,96 , and $168 \mathrm{~h}$ of drought stress, and after $96 \mathrm{~h}$ of recovery. Herbicide treatment did not alter substantially the phenotype and growth parameters of the above-ground plant parts. It provoked a moderate increase in phenolics, thiol-containing compounds, catalase, superoxide dismutase, glutathione reductase, and $\mathrm{H}_{2} \mathrm{O}_{2}$. However, significant variations of malondialdehyde, proline, and peroxidase activity caused by the sole application of the herbicide were not detected during the experimental period. Drought and herbicide + drought treatments caused significant growth inhibition, increased oxidative stress markers, and activation of enzymatic and non-enzymatic antioxidant defense reaching the highest levels at $168 \mathrm{~h}$ of stress. Plant growth was restored after $96 \mathrm{~h}$ of recovery and the levels of the monitored biochemical parameters showed a substantial decline. The herbicide provoked an extra load of oxidative stress-related biochemical components which did not aggravate the phenotypic and growth traits of plants subjected to drought, since they exhibited a good physiological status upon recovery.
\end{abstract}

Keywords: antioxidants; drought; herbicide; stress markers; wheat

\section{Introduction}

During the last decades, human activity and the unwise use of natural resources has contributed to the continually deepening adverse climate changes on Earth. NASA reports [1] show that since the late twentieth century the average temperature has increased by $0.8{ }^{\circ} \mathrm{C}$, which along with the increasing frequency of climatic anomalies such as periods of heavy drought or torrential rainfalls cause significant losses in the yield of important crops. Based on a number of climate models, it is predicted that in many regions the environmental changes will deepen and lead to even more tangible decline in plant productivity [2].

Drought is one of the environmental factors affecting almost all aspects of plant development. Physiological drought in plants can occur due to water scarcity or soil 
water unavailability, soil salinity, and elevated air temperature [3]. Water deficiency adversely affects the germination, growth, and reproduction of plants. This stressor is directly linked to decrease of crop productivity since it disrupts major biochemical and physiological processes.

Weeds present another important limiting factor for crop breeding. The discovery of chemical substances selectively destroying weeds benefits crop growth and insures high crop yields. In this respect, herbicides as plant protection products against weeds are an integral part of the modern agriculture. Herbicidal active compounds can be separated into four general groups according to their mechanism of action: herbicides affecting photosynthesis or photosynthetic pigments; auxin-type herbicides; inhibitors of amino acid biosynthesis, and inhibitors of fatty acid biosynthesis. According to the sensitivity of plants to herbicidal action, herbicides are classified as selective, affecting certain types of plant species, and total, affecting all plant species.

Serrate $^{\circledR}$ (Syngenta, Bazel, Switzerland) is a herbicide consisting of two active substances: clodinafop-propargyl (prop-2-ynyl(R)-2-[4-(5-chloro-3-fluoro-2-pyridyloxy)phenoxy] propionate) inhibitor of acetyl co-enzyme A carboxylase, which is essential for the fatty acids biosynthesis; and pyroxsulam ([N-(5,7-dimethoxy [1,2,4]triazolo [1,5-a]pyrimidin-2 -yl)2-methoxy-4-(trifluoromethyl)pyridine-3-sulfonamide]) inhibitor of acetolactate synthase enzyme, which catalyzes a key step in the biosynthesis of the branched-chain amino acids. The preparation contains also a safener and is highly effective in controlling annual grass and broadleaf weeds in cereal crops. The herbicide is systemic and is selective for wheat, rye, and triticale, which all are tolerant to the preparation.

The cultivation of plants under sub-optimal conditions is accompanied by unfavorable oxidative events in the cells, whereby reactive oxygen species (ROS) are formed as a universal physiological response to various types of abiotic stress factors, including drought. Accumulation of free radicals can induce chain oxidation reactions leading to the formation of lipid peroxides, which damage the biomembranes [4,5]. This disrupts fundamental physiological processes and adversely affects the physiological status of the plant organism. Numerous publications investigate the effect of a single stress factor (low or high temperature, salinization, radiation, herbicides, water or mineral deficiency, heavy metals, etc.) on the physiological status of the plant and/or the possibility of reducing the impact of the stress [6-10]. Under natural conditions, however, plants are rarely exposed to a single stress factor. Usually, plants are subjected to the simultaneous influence of several stressors. Often their additive damaging impact exceeds by far the effect of their self-administration, a phenomenon called cross-synergism [11,12]. Such an additive damaging effect has been observed in atrazine-treated maize grown under high soil moisture and low temperatures [13]. Exposure of drought-stressed wheat or tobacco plants to additional high-temperature had a stronger negative impact compared to the alone-applied drought [14-16].

Previously there have been published results describing studies in which plants subjected to a single stress agent exhibited improved tolerance to the subsequent adverse environmental conditions (cross-adaptation). For example, cross-adaptation has been reported in rice subjected to PEG and $\mathrm{LiCl}$ [17]; cucumber seedlings after combined heat and salinization [18]; grapes after drought combined with UV-B radiation [19]. Increased resistance has been observed in drought-stressed pea plants treated with high temperature [20]. An increase in salinity resistance has been observed in some medicinal plants preliminary irradiated with UV-B, and a similar effect was found also after $\mathrm{NaCl}$ pretreatment and subsequent UV-B irradiation [21]. Cross-adaptation has been also documented in barley treated with different heavy metals [22]. Many ambiguous points of discussion regarding the interaction between two and/or more stressors still exist and there are a number of gaps related to the understanding of the mechanisms by which cross-adaptation and cross-synergism operate.

Plants treated with herbicides, similarly to those grown under various abiotic stress conditions, are subjected to enhanced attacks by Reactive Oxygen Species (ROS) $[23,24]$. 
Plants have developed complex endogenous hormonal, enzymatic and non-enzymatic protective systems to overcome the adverse effects of ROS that have evolved during their evolution [4]. These mechanisms are implicated also in the processing or neutralization of herbicides by converting them to non-toxic metabolites [25]. The use of herbicides is usually not recommended on crops subjected to stress such as flooding, frost, drought, nutritional deficiency, etc., and often it is explicitly stated in the instructions for application provided by the manufacturers. However, there is no information on how subsequent adverse environmental conditions could affect the physiological status of herbicide-treated plants, which often occurs in the field. The question whether and how the herbicide will affect the physiological responses of plants when exposed to the effects of a subsequent abiotic stress factor remain unclear. Will the herbicide application cause a cross-synergism resulting in exaggerated negative effects on the physiological status of the treated plants, or will it possibly improve their adaptive capacity and stress tolerance? The study addresses this yet unresolved question by evaluating the physiological responses of wheat seedlings to soil drought after application of the selective herbicide Serrate ${ }^{\circledR}$.

\section{Results}

\subsection{Growth Parameters}

The changes of crop phenotypic and growth traits due to drought stress and herbicide treatment are presented in Figures 1 and 2. Apparently, the herbicide application did not provoke significant alterations in plant growth and fresh biomass. However, it affected the dry weight which increased by $24 \%$ at $168 \mathrm{~h}$ of drought and by $27 \%$ at $96 \mathrm{~h}$ of recovery. This was linked to reduced water content (by $9 \%$ at $168 \mathrm{~h}$ of drought and by $18 \%$ at $96 \mathrm{~h}$ of recovery) and yellowing of the older leaves. The alterations caused by drought and drought + herbicide treatments were similar and depended on drought duration. Significant wilting (Figure 1A) and inhibition of plant elongation growth (by 10\%), fresh weight (by $54 \%$ ), and water content (by $56 \%$ ) at $96 \mathrm{~h}$ of stress was observed (Figure 2).
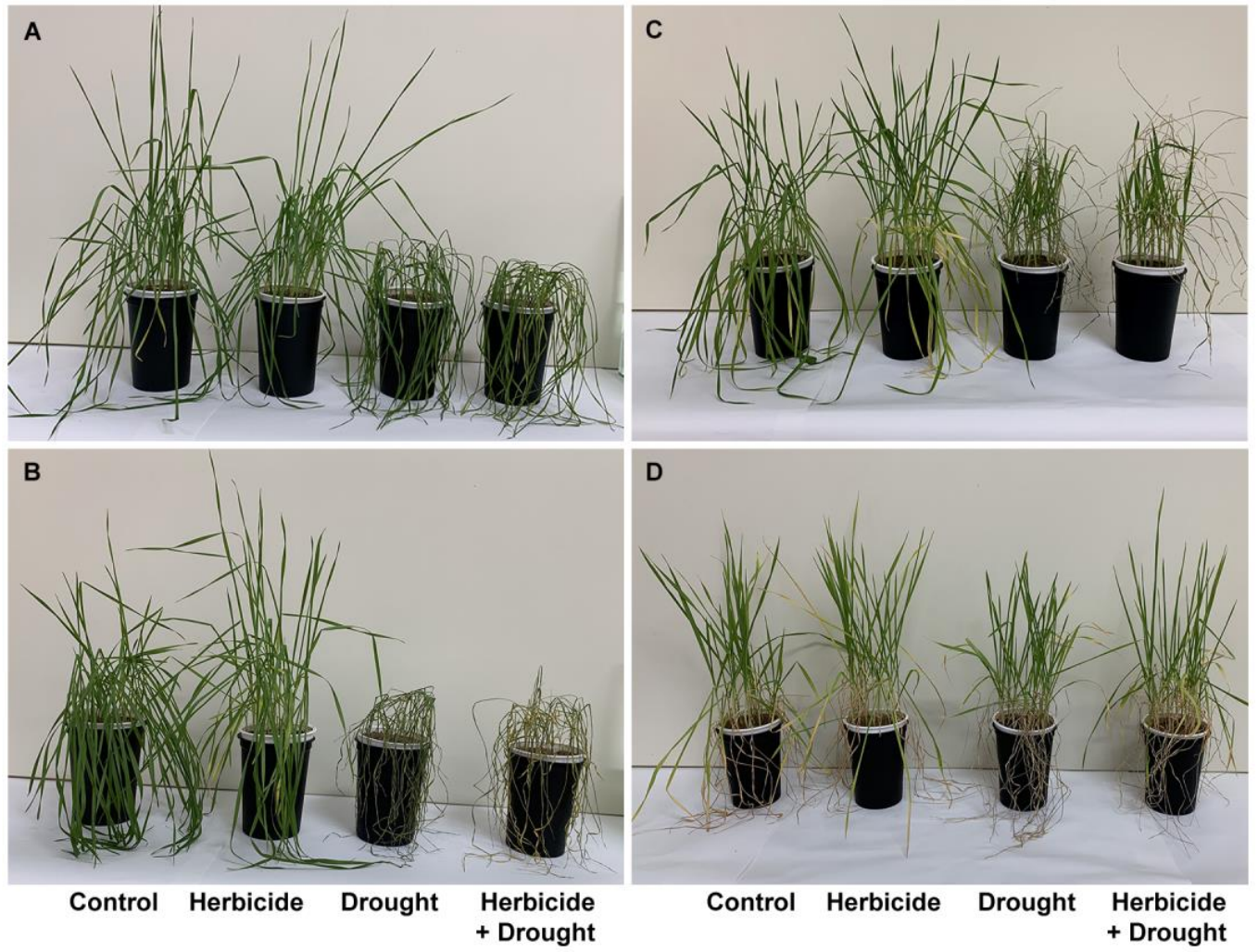

Figure 1. Phenotypic traits of wheat plants treated with herbicide and subjected to drought stress. (A) $96 \mathrm{~h}$ of drought, (B) $168 \mathrm{~h}$ of drought, (C) $96 \mathrm{~h}$ of recovery after restoring the normal irrigation regime, (D) 24 days of recovery. 


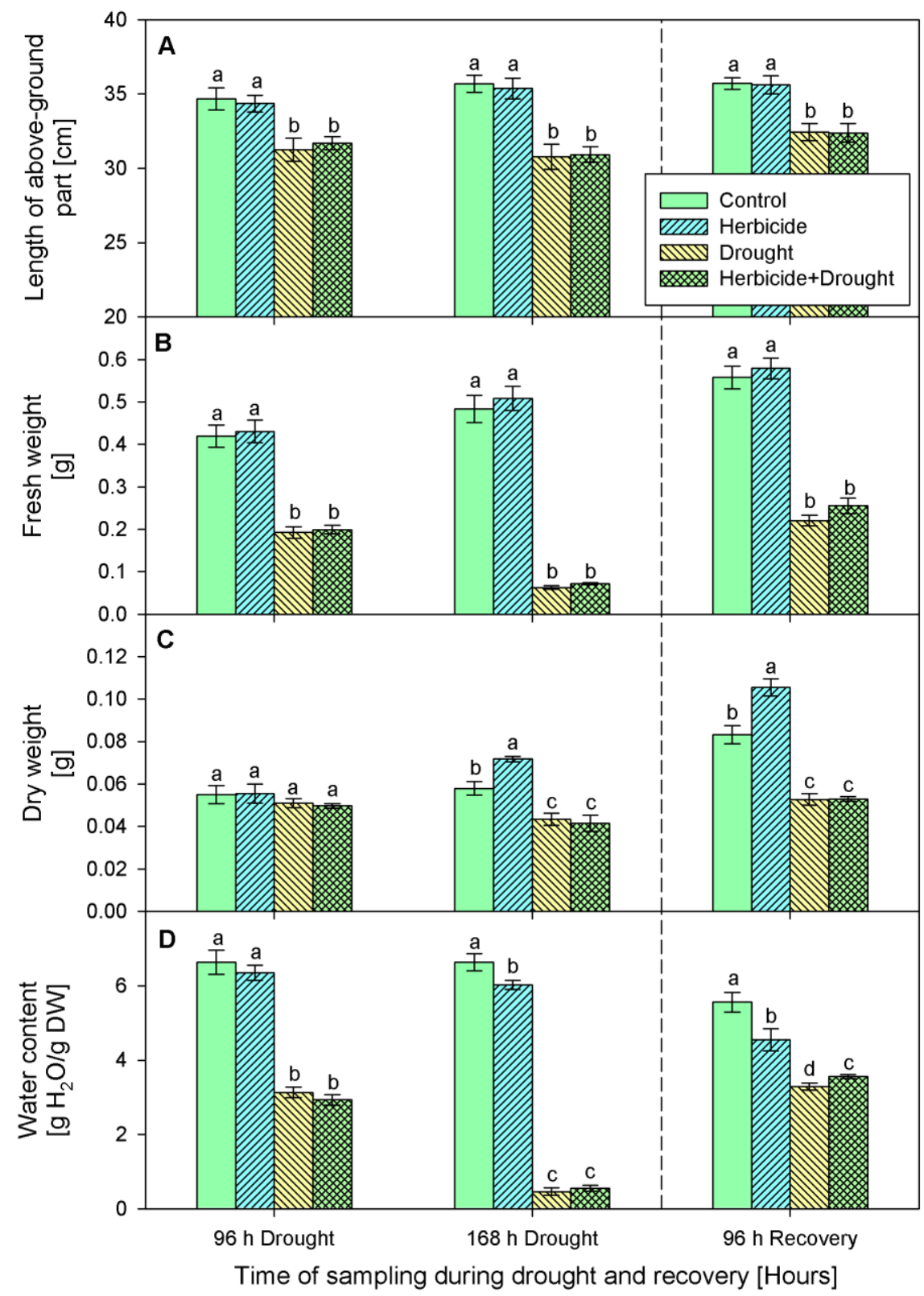

Figure 2. Length (A), fresh weight (B), dry weight (C), water content (D) of above-ground part of wheat treated with herbicide and exposed to drought. Control values at $0 \mathrm{~h}$ : (A) $32.1 \pm 0.4 \mathrm{~cm}$; (B) $0.331 \pm 0.011 \mathrm{~g}$; (C) $0.041 \pm 0.001 \mathrm{~g}$; (D) $6.922 \pm 0.061 \mathrm{~g}$. The same letter means lack of statistical significance between treatments $(n=3, p<0.05)$.

These negative effects were stronger at $168 \mathrm{~h}$ of drought stress with $18 \%$ growth inhibition, reduction of fresh weight by $87 \%$, and water loss by $93 \%$ (Figures $1 \mathrm{~B}$ and 2). A reduction in dry weight (by $28 \%$ ) was observed also. After restoring the irrigation, the drought-stressed plants resumed their growth (Figure 1C) and the plants acquired normal status comparable to the controls after 24 days of recovery (Figure 1D). The measured water content reached approximately $59 \%$ of the control level in drought-treated and $64 \%$ in combine-treated at $96 \mathrm{~h}$ of recovery (Figure 2D). Accordingly, fresh weight increased up to $40 \%$ in drought-treated and up to $45 \%$ in combine-treated plants as compared to the control (Figure 2B). Length of above-ground part and dry weight were not significantly altered and remained lower than the respective controls (Figure 2A,C). 


\subsection{Stress Markers Content}

The changes in malonedialdehyde (MDA) content of plants treated only with herbicide during the first $96 \mathrm{~h}$ of drought and after recovery were insignificant compared to the respective control (Figure $3 \mathrm{~A}$ ). At $168 \mathrm{~h}$ a slight increase by $20 \%$ was detected. MDA accumulation was the most prominent in both drought stressed variants-drought only and drought in combination with herbicide. After $96 \mathrm{~h}$ of stress MDA content increased significantly by $129 \%$ (drought stressed) and by $153 \%$ (herbicide treatment followed by drought). Later, at $168 \mathrm{~h}$ of stress, its amount drastically raised reaching $424 \%$ and $576 \%$ respectively. After $96 \mathrm{~h}$ of recovery MDA quantity dropped to the control levels and remained slightly increased by $11 \%$ only in the drought-stressed seedlings.

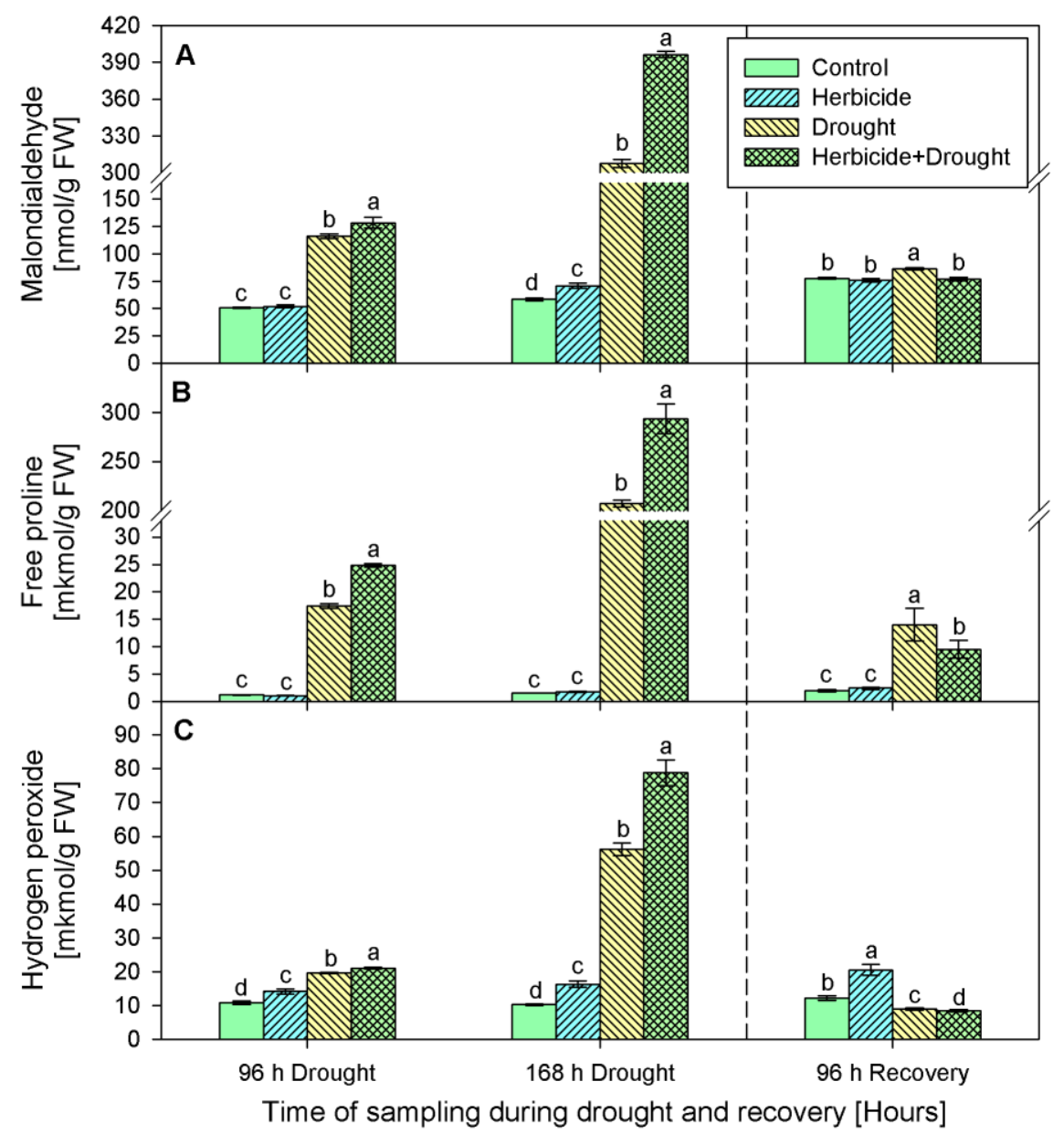

Figure 3. Content of malondialdehyde (A), free proline (B), and hydrogen peroxide (C) in leaves of wheat treated with herbicide and exposed to drought. Control values at $0 \mathrm{~h}$ : (A) $57.210 \pm 4.104$; (B) $0.837 \pm 0.039$; (C) $6.568 \pm 0.696$. The same letter means lack of statistical significance between treatments $(n=3, p<0.05)$.

Similar alterations were found in proline content (Figure 3B). During the stress and recovery periods proline level in herbicide treated plants varied insignificantly as compared to the respective controls. However, drought stress provoked considerable increase in proline content as follows: 15-fold (after $96 \mathrm{~h}$ of drought), 134-fold (after $168 \mathrm{~h}$ of drought), and 7-fold (after $96 \mathrm{~h}$ of recovery) in drought treated seedlings and 21-fold, 190-fold, and 5 -fold, respectively, in the plants subjected to the combined herbicide+drought treatment.

Hydrogen peroxide (Figure 3C) was continuously accumulated in the herbicide treatment group by $31 \%$ ( $96 \mathrm{~h}$ of drought), 58\% (168 h of drought), and 70\% (96 $\mathrm{h}$ of recovery). Drought caused an increase of $\mathrm{H}_{2} \mathrm{O}_{2}$ by $82 \%$ ( $96 \mathrm{~h}$ of drought) and by $446 \%$ ( $168 \mathrm{~h}$ of drought). Upon recovery $\mathrm{H}_{2} \mathrm{O}_{2}$ content was below the control levels by $26 \%$. The com- 
bined treatment provoked more prominent changes in this parameter - initially, at $96 \mathrm{~h}$ of drought, $\mathrm{H}_{2} \mathrm{O}_{2}$ was augmented 2-fold, followed by a 7.5-fold increase (168 h of drought) and sharp drop after recovery which was $30 \%$ below the control levels.

\subsection{Activity of Antioxidant Enzymes}

Increased catalase activity (Figure 4A) was found in drought and drought-herbicide treated seedlings during the whole experimental period. The highest levels of enzymatic activity were detected during the first $96 \mathrm{~h}$ of drought, then after the recovery catalase tended to decrease, but remained higher than the controls. The catalase activity changes provoked by the herbicide alone were less prominent.

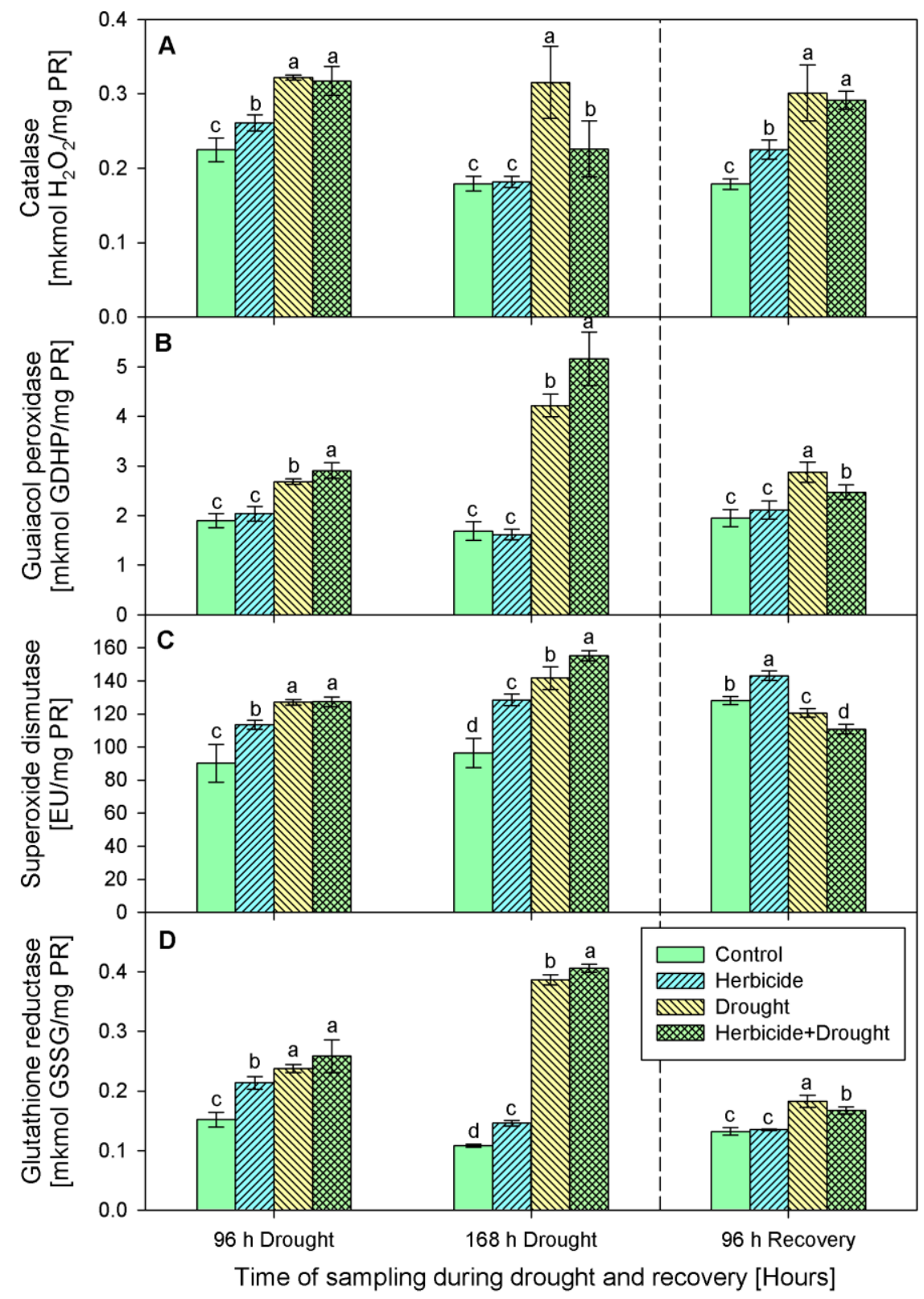

Figure 4. Activity of catalase (A), guaiacol peroxidase (B), superoxide dismutase (C), and glutathione reductase $(\mathrm{D})$ in leaves of wheat treated with herbicide and exposed to drought. Control values at 0 h: (A) $0.211 \pm 0.020$; (B) $1.767 \pm 0.192$; (C) $60.280 \pm 9.942$; (D) $0.158 \pm 0.012$. The same letter means lack of statistical significance between treatments $(n=3, p<0.05)$. 
Guaiacol peroxidase activity (Figure 4B) was not changed significantly by the herbicide as compared to the respective control levels at each sampling point of the experimental period. Drought stress applied in both variants-alone and in combination with the herbicide provoked a noticeable increase of the guaiacol peroxidase activity and it reached $181 \%$ at $168 \mathrm{~h}$ of drought in the herbicide+drought-treated seedlings. Elevated SOD (Figure 4C) was detected during the first $168 \mathrm{~h}$ of stress in all experimental groups. Upon recovery, the activity dropped below the control levels except in the plants treated only with herbicide where it remained above the controls by $11 \%$. Glutathione reductase (GR) activity (Figure 4D) was consistently induced by all the treatments during the stress period, and the highest activity was detected in drought-stressed and herbicide+drought-treated seedlings-up to fourfold as compared to the control level. GR activity returned to the control levels in herbicide-treated seedlings after $96 \mathrm{~h}$ of recovery, while in the droughtstressed and drought+herbicide-treated group it remained slightly higher.

\subsection{Content of Non-Enzymatic Antioxidants}

Phenolics content progressively increased after the herbicide treatment by $29 \%$ (at $96 \mathrm{~h}$-stress sampling point), by $38 \%$ (at $168 \mathrm{~h}$ of the stress program), and by $41 \%$, measured at the recovery sampling point (Figure 5A). A similar trend was observed in the content of thiol-containing compounds (Figure 5B). Their amounts continuously increased in the samples derived from herbicide-only treated plants as follows: by $28 \%$ (at $96 \mathrm{~h}$ ), $52 \%$ (at $168 \mathrm{~h}$ ), and $60 \%$ (after recovery).

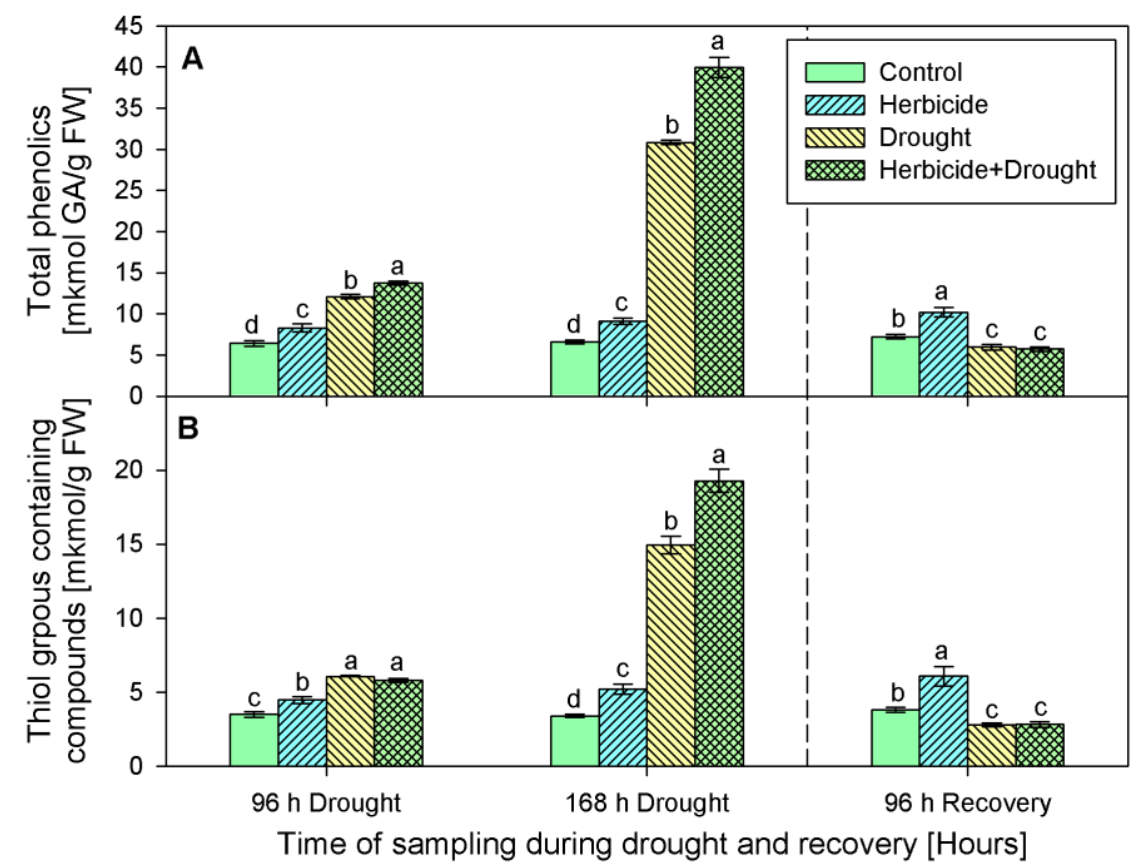

Figure 5. Content of total phenolics (A), and thiol groups containing compounds (B) in leaves of wheat treated with herbicide and exposed to drought. Control values at 0 h: (A) $4.557 \pm 0.223$; (B) $2.198 \pm 0.115$. The same letter means lack of statistical significance between treatments $(n=3$, $p<0.05)$.

Drought, alone or in combination with the herbicide, also caused an increase in the levels of these antioxidants. Phenolics raised by $89 \%$ and $367 \%$ in drought-stressed seedlings, and by $115 \%$ and $506 \%$ in the herbicide+drought combination-treated plants (Figure 5A). Phenolics content dropped below the control (by 20\%) upon recovery. Significant differences in thiol-containing compounds (-SH) between both drought-stressed variants during the first $96 \mathrm{~h}$ of stress were not detected. An increase in their quantity by approximately $70 \%$ was found in both experimental groups at this sampling point (i.e., $96 \mathrm{~h}$ of drought). A peak of -SH content was found after $168 \mathrm{~h}$ of stress - drought alone led to an increase 
by $338 \%$, and the herbicide treatment caused an additional increase with up to $465 \%$ under drought stress conditions. The measured thiol-containing compounds upon recovery were lower than the control by $27 \%$ (Figure 5B).

\section{Discussion}

As an environmental stress factor, drought disrupts plant metabolism and physiological responses. Drought stress elicits excessive formation of ROS, such as $\mathrm{O}_{2}{ }^{\bullet-}$ and $\mathrm{H}_{2} \mathrm{O}_{2}$ in plant cells, which provokes injury of cellular membranes due to peroxidation of membrane phospholipids, which causes accumulation of MDA [26]. To scavenge the extra generated ROS, plants activate an efficient antioxidant enzymatic and non-enzymatic defense systems [26,27]. Enzymatic antioxidants include enzymes like superoxide dismutase (SOD), catalase (CAT), ascorbate peroxidase (APX), glutathione peroxidase (POD), and glutathione reductase (GR). SOD acts as a front line shield converting $\mathrm{O}_{2}{ }^{\bullet-}$ to $\mathrm{H}_{2} \mathrm{O}_{2}$. Then CAT, APX, and POD detoxify $\mathrm{H}_{2} \mathrm{O}_{2}$ forming $\mathrm{H}_{2} \mathrm{O}$. Non-enzymatic antioxidants including glutathione (GSH), ascorbic acid (AsA), carotenoids, tocopherols, and some phenolics like flavonoids are also involved in maintaining ROS homeostasis in plants [26,27]. Wheat is particularly vulnerable to drought at the flowering and grain development stages, but it can tolerate mild and moderate drought during vegetation [28], thus young droughttreated plants are capable to recover after the normal water supply is restored $[29,30]$ as it was confirmed in our experiments (Figures 1 and 2). Wheat also tolerates some selective herbicides like Serrate ${ }^{\circledR}$ as evident by the lack of growth inhibition in herbicide-treated plants (Figure 2). Our results present biochemical responses to treatment with Serrate ${ }^{\circledR}$ and subsequent stress during the early vegetative stage in winter wheat, information which to our knowledge was missing so far. To fill in this gap we assessed the levels of some stress markers, non-enzymatic, and enzymatic antioxidants in treated with herbicide and drought wheat seedlings during the stress and recovery phases.

We detected a significant boost of stress markers MDA, $\mathrm{H}_{2} \mathrm{O}_{2}$, and proline in droughtstressed plants (Figure 3) which is in line with the well-established fact that water deprivation induces generation of ROS, which can diffuse across the cell biomembranes and cause cell damage. Similar increase in the stress markers content was documented previously in wheat [31-33] and tobacco [16] drought-stressed plants. Along with the increase in the stress markers, a significant induction of antioxidant enzymes, non-enzymatic antioxidants, and compatible solutes in wheat was reported by Abid et al. [33], Sallam et al. [34] and the references therein. An activation of plant defense systems was observed in the present study as well and this was manifested by the substantial progressive increase of enzymatic and non-enzymatic antioxidants (Figures 4 and 5). Similar patterns have been reported by other authors $[16,33,35,36]$ in other model systems. Usually, when a certain environmental constrain is no longer present, plant metabolism enters into a recovery regime that tends to bring the physiological parameters in the plant system to their initial levels $[31,35,37]$. Accordingly, we found that after restoring the irrigation, there was a significant decline in values of the measured traits (Figures 3-5) as compared to those detected at $168 \mathrm{~h}$ of drought, except for the catalase activity. This drop indicated that upon recovery, plants were capable to regain normal physiological status. As it was reported earlier, re-watering of drought-stressed plants restored partially the plant metabolism in tobacco [16] and wheat $[31,33]$.

Limited number of articles reported the alterations in some agronomic, physiological and/or biochemical traits after individual application of clodinafop-propargyl [38-41] and pyroxsulam $[42,43]$. Our study communicates the results describing the biochemical alterations in wheat after application of Serrate ${ }^{\circledR}$, which contains both active ingredients clodinafop-propargyl and pyroxsulam. We observed that the herbicide alone did not cause significant changes in most of the studied parameters, including the monitored stress markers (MDA and proline), which suggests that the herbicide treatment does not result in strong oxidative stress events. This is in line with the characteristics of the preparation provided by the manufacturer stating that wheat is tolerant to Serrate ${ }^{\circledR}$ application. Rela- 
tively higher values of $\mathrm{H}_{2} \mathrm{O}_{2}$, non-enzymatic antioxidants, and SOD activity were found in herbicide-treated plants, which remained steadily elevated throughout the experimental period. Temporary increases were also observed in GR and catalase activity. Moderately high levels of $\mathrm{H}_{2} \mathrm{O}_{2}$ seem to function as a signal that triggers protective responses [44,45]. In accordance with this, our results suggest that higher herbicide-induced levels of $\mathrm{H}_{2} \mathrm{O}_{2}$ might trigger antioxidant protection judging by the increased quantity of non-enzymatic antioxidants and SOD activity measured in the herbicide-treated plants long after the application as evident from the measurements taken at the recovery sampling point. Simultaneous or subsequent occurrence of more than one unfavorable circumstances can influence either positively or negatively the plants physiological status [46]. The positive physiological reactions are characterized as cross-adaptation or cross-tolerance that induce adaptive response rendering tolerance to a follow-up stressor. This phenomenon is known as priming and it has been related to a more efficient activation of the plant defense responses [45,47-49]. The results of priming may last for several days via induction of the so-called stress memory $[45,47,48]$. The stress memory enables plants to be more tolerant to future environmental constraints [47] and it can be triggered by mild biotic or abiotic stressors, by beneficial microbes, as well as by chemical priming through the application of natural and synthetic compounds $[27,48,49]$. In addition some plant protection chemicals as herbicides and fungicides are able to act as cross-tolerance elicitors [48,49]. In most cases, during and after priming, plants generate ROS, especially $\mathrm{H}_{2} \mathrm{O}_{2}$ that can act as early response signaling molecule to boost several antioxidant mechanisms, which plants memorize [45]. This facilitates the more rapid and efficient plant response to the subsequent stress.

On the opposite, cross-synergism may occur as an additive effect of negative consequences of two or more adverse factors $[14,15,32]$. We found that combined treatment caused more dramatic alteration in biochemical traits during the stress period as compared to drought treatment alone. The levels of stress markers (Figure 3) and antioxidant defense machinery (Figures 4 and 5) were higher in herbicide+drought combination-treated plants than those in drought-stressed only. Nonetheless the drastically different levels of physiological responses during the stress period, upon restored irrigation the biochemical parameters tended to recover to a similar state.

We suggest that herbicide application did not provoke a typical cross-synergistic response in the drought-stressed plants since they did not exhibit worsen phenotypic and growth traits, and they recovered successfully after re-watering, particularly evident after a prolonged recovery period (Figure 1D).

\section{Materials and Methods}

\subsection{Plant Material and Treatments}

Wheat (Triticum aestivum L., cv. Sadovo-1) was obtained from the Institute of Plant Genetic Resources (Sadovo, Bulgaria). The plants were grown under controlled conditions $\left(22{ }^{\circ} \mathrm{C} / 17^{\circ} \mathrm{C}\right.$ (day/night) temperatures, $16 / 8 \mathrm{~h}$ (day/night) photoperiod, and $60 \%$ relative air humidity) on pots filled with leached meadow cinnamon soil ( $\mathrm{pH}$ 6.2) delivered from the Institute's experimental field near Sofia. Each pot consisted of 20 plants. Seventeenday-old seedlings (2-3 leaf phase) were treated with aqueous solution of the herbicide Serrate ${ }^{\circledR}$ according to manufacturer's instructions $(25 \mathrm{~g} / \mathrm{d})$. After $72 \mathrm{~h}$ part of the plants were exposed to drought stress by withholding watering for 7 days to reach water deficit of $60 \%$ below the normally irrigated control variants $[29,31,50]$. Then the normal irrigation was restored, and the stressed plants were left to recover for 4 days.

The plants were divided into the following groups:

1. Normally irrigated control plants.

2. Normally irrigated plants treated with herbicide.

3. Drought stressed plants.

4. Plants treated with herbicide and subsequently exposed to drought stress.

Samples were collected at 0,96 , and $168 \mathrm{~h}$ of drought and after $96 \mathrm{~h}$ of recovery. 
Fresh weight was measured immediately after harvesting the leaves. The dry weight was obtained by drying the same leaf material for several days in an oven at $80^{\circ} \mathrm{C}$ until constant weight was measured. Leaf water content was calculated according to the formula $\mathrm{WC}=(\mathrm{FW}-\mathrm{DW}) / \mathrm{DW}[51]$.

Samples for the biochemical analyses were frozen in liquid nitrogen and stored at $-80{ }^{\circ} \mathrm{C}$.

\subsection{Biochemical Analyses}

Approximately $250 \mathrm{mg}$ of leaf material was grinded in $0.1 \%$ cold trichloroacetic acid (TCA) and was centrifuged for $30 \mathrm{~min}\left(15,000 \times g, 4^{\circ} \mathrm{C}\right)$. The resulted supernatant was used for analyses of the stress markers.

Free proline was determined according to [52] with some modifications. Reaction mixture contained $0.5 \mathrm{~mL}$ supernatant, $0.5 \mathrm{~mL} \mathrm{0.1 \%} \mathrm{TCA,} 1 \mathrm{~mL}$ conc. $\mathrm{CH}_{3} \mathrm{COOH}$, and $1 \mathrm{~mL}$ ninhydrin reagent ( $1.25 \mathrm{~g}$ ninhydrin, $30 \mathrm{~mL}$ conc. $\left.\mathrm{CH}_{3} \mathrm{COOH}, 20 \mathrm{~mL} 6 \mathrm{M} \mathrm{H}_{3} \mathrm{PO}_{4}\right)$. Supernatant was derivatized in the ninhydrin reagent for $1 \mathrm{~h}$ at $100{ }^{\circ} \mathrm{C}$. After stopping the reaction in ice bath, the absorbance was read at $520 \mathrm{~nm}$.

The level of biomembrane lipid peroxidation was assessed by the concentration of malondialdehyde in the plant tissues according to [53]. Five hundred microliters of supernatant was incubated with $1 \mathrm{~mL} 0.5 \%$ thiobarbituric acid in 20\% TCA for $45 \mathrm{~min}$ at $100{ }^{\circ} \mathrm{C}$. The absorbance of the resulting thiobarbituric reaction products was read at $532 \mathrm{~nm}$ and $600 \mathrm{~nm}$. The content of MDA was calculated by using of $155 \mathrm{mM}^{-1} \mathrm{~cm}^{-1}$ extinction coefficient. The hydrogen peroxide concentration was measured after incubation of $75 \mu \mathrm{L}$ supernatant with $1 \mathrm{M} \mathrm{KI}(1: 1 v / v)$ for $1 \mathrm{~h}$ in darkness [54]. The absorbance was read at $350 \mathrm{~nm}$, and the concentration of $\mathrm{H}_{2} \mathrm{O}_{2}$ was calculated by a standard curve. The total content of the phenolic compounds was measured by following the method described by Swain and Goldstein [55] with some modifications. The reaction mixture consisted of $20 \mu \mathrm{L}$ supernatant, $130 \mu \mathrm{L}$ distilled $\mathrm{H}_{2} \mathrm{O}$ and $50 \mu \mathrm{L}$ Folin-Ciocalteu reagent. After $3 \mathrm{~min}$ incubation $50 \mu \mathrm{L} 1 \mathrm{M} \mathrm{Na}_{2} \mathrm{CO}_{3}$ was added, and the reaction was left to develop for $2 \mathrm{~h}$ at room temperature. The absorbance was read at $725 \mathrm{~nm}$, and the results were calculated by a standard curve prepared with known concentrations of gallic acid. The content of free thiol-groups-containing compounds was measured using Elman's reagent [56]. The reaction mixture contained $40 \mu \mathrm{L}$ supernatant and $150 \mu \mathrm{L}$ Elman's reagent. The absorbance was read at $412 \mathrm{~nm}$ after incubation for $10 \mathrm{~min}$ at room temperature.

For determination of the antioxidant enzyme activities approximately $200 \mathrm{mg}$ leaf material was homogenized in cold $100 \mathrm{mM}$ potassium phosphate buffer $\left(\mathrm{K}_{2} \mathrm{HPO}_{4} / \mathrm{KH}_{2} \mathrm{PO}_{4}\right.$, $\mathrm{pH}$ 7.0, supplied with $1 \mathrm{mM}$ EDTA) and 1\% PVP. The homogenate was centrifuged at $15,000 \times g$ for $30 \mathrm{~min}$ at $4{ }^{\circ} \mathrm{C}$. Catalase (EC 1.11.1.6) activity was measured by monitoring the degradation of $\mathrm{H}_{2} \mathrm{O}_{2}$ [57]. The reaction mixture consisted $50 \mu \mathrm{L}$ supernatant, $2.930 \mathrm{~mL}$ reaction buffer $\left(0.05 \mathrm{M} \mathrm{K}_{2} \mathrm{HPO}_{4} / \mathrm{KH}_{2} \mathrm{PO}_{4}, \mathrm{pH} 7.0\right)$, and $20 \mu \mathrm{L} 6 \% \mathrm{H}_{2} \mathrm{O}_{2}$. The activity was measured by monitoring the degradation of $\mathrm{H}_{2} \mathrm{O}_{2}$ for $1 \mathrm{~min}$ at $412 \mathrm{~nm}$. Guaiacol peroxidase (EC 1.11.1.7) activity was determined using guaiacol as electron donor. The reaction mixture consisted $20 \mu \mathrm{L}$ supernatant, $1.1 \mathrm{~mL}$ reaction buffer $\left(0.05 \mathrm{M} \mathrm{K}_{2} \mathrm{HPO}_{4} / \mathrm{KH}_{2} \mathrm{PO}_{4}, \mathrm{pH} 7.0\right)$, $360 \mu \mathrm{L} 1 \%$ guaiacol, and $20 \mu \mathrm{L} \mathrm{15 \%} \mathrm{H}_{2} \mathrm{O}_{2}$. The change of absorbance was followed at $470 \mathrm{~nm}$ [58]. The inhibition of the photochemical reduction of nitroblue tetrazolium was used to determine the activity of superoxide dismutase (EC 1.15.1.1). The amount of enzyme needed to cause a 50\% inhibition was defined as one unit of SOD [59]. The activity of glutathione reductase was measured according to the method described by Smith et al. [60]. The reaction mixture consisted $100 \mu \mathrm{L}$ supernatant, $1.180 \mathrm{~mL}$ reaction buffer (0.05M K $\mathrm{HPO}_{4} / \mathrm{KH}_{2} \mathrm{PO}_{4}, \mathrm{pH} 7.5,1 \mathrm{mM}$ EDTA), $20 \mu \mathrm{L} 50 \mathrm{mM}$ DTNB, $0.1 \mathrm{~mL}$ $7.5 \mathrm{mM}$ GSSG, $0.1 \mathrm{~mL} 1.5 \mathrm{mM}$ NADPH. The reaction was monitored at $412 \mathrm{~nm}$ for $60 \mathrm{~s}$. All enzyme activities were calculated on a protein basis. The total soluble protein content was measured according to Bradford [61].

The herbicide Serrate ${ }^{\circledR}$ was purchased from Syngenta. All chemicals used for the biochemical analyses were purchased from Sigma. The measurements of the stress markers were conducted on Multiskan Spectrum spectrophotometer with microplate reader 
(Thermo Electron Corporation, Vantaa, Finland). The enzyme activities were measured on Shimadzu UV-1601 spectrophotometer (Shimadzu, Kyoto, Japan). A refrigerated Sigma 2-16K centrifuge (SciQuip, Wem, UK) was also used in the experiments.

\subsection{Statistics}

The experiments were repeated three times. The samples were collected in three replicates each. The data presented in the Figures are mean values \pm SE. The significance of the treatments was assessed by one-way ANOVA with post-hoc Duncan's multiple range test at $p<0.05$.

\section{Conclusions}

The application of Serrate ${ }^{\circledR}$ did not alter considerably biochemical, phenotypic, and growth traits of wheat plants during the experimental period. Drought stress substantially inhibited plant growth and provoked an increase in the studied biochemical parameters. We found that the stress markers, enzymatic and non-enzymatic antioxidant defense were additionally increased during the stress period after the combined herbicide+drought treatment. The recovery of the herbicide + drought treated plants was comparable to the one witnessed in the individuals subjected only to drought. It could be concluded that Serrate $^{\circledR}$ modulates the biochemical responses of wheat seedlings grown under drought stress but its action under adverse environment could not be explicitly characterized as cross-synergism or cross-adaptation without additional analyses.

Author Contributions: I.S. and D.T.-conceptualized and coordinated the research; L.D., Z.K., and D.T.-grown and treated the plants; I.S., D.T., E.S., L.B., L.D., and Z.K.- performed the laboratory analyses, collected, and interpreted the data; I.S.- prepared Figures; D.T. and Z.K.-prepared original draft of manuscript; I.S. and D.T.--reviewed and edited the manuscript. All authors have read and agreed to the published version of the manuscript.

Funding: This research was supported by the Bulgarian National Scientific Fund (BNSF) grant KP-06-N36/3 (30.09.2020).

Institutional Review Board Statement: Not applicable.

Informed Consent Statement: Not applicable.

Data Availability Statement: Not applicable.

Conflicts of Interest: The authors declare no conflict of interest.

\section{References}

1. NASA, World of Change: Global Temperatures. Available online: https:// earthobservatory.nasa.gov/Features/WorldOfChange/ decadaltemp.php (accessed on 19 March 2021).

2. Hatfield, J.L.; Prueger, J.H. Temperature extremes: Effect on plant growth and development. Weather. Clim. Extrem. 2015, 10, 4-10. [CrossRef]

3. Hasanuzzaman, M.; Mahmud, J.A.; Anee, T.I.; Nahar, K.; Islam, M.T. Drought stress tolerance in wheat: Omics approaches in understanding and enhancing antioxidant defense. In Abiotic Stress-Mediated Sensing and Signaling in Plants: An Omics Perspective; Zargar, S., Zargar, M., Eds.; Springer: Berlin/Heidelberg, Germany, 2018; pp. 267-307.

4. Gill, S.; Tuteja, N. Reactive oxygen species and antioxidant machinery in abiotic stress tolerance in crop plants. Plant Physiol. Biochem. 2010, 48, 909-930. [CrossRef]

5. Fahad, S.; Bajwa, A.A.; Nazir, U.; Anjum, S.A.; Farooq, A.; Zohaib, A.; Sadia, S.; Nasim, W.; Adkins, S.; Saud, S.; et al. Crop Production under Drought and Heat Stress: Plant Responses and Management Options. Front. Plant Sci. 2017, 8, 1147. [CrossRef]

6. Jallouli, S.; Ayadi, S.; Landi, S.; Capasso, G.; Santini, G.; Chamekh, Z.; Zouari, I.; Azaiez, F.E.B.; Trifa, Y.; Esposito, S. Physi-ological and molecular osmotic stress responses in three durum wheat (Triticum turgidum ssp durum) genotypes. Agronomy 2019, 9, 550. [CrossRef]

7. Landi, S.; Hausman, J.-F.; Guerriero, G.; Esposito, S. Poaceae vs. Abiotic Stress: Focus on Drought and Salt Stress, Recent Insights and Perspectives. Front. Plant Sci. 2017, 8, 1214. [CrossRef] [PubMed]

8. Kataria, S.; Jain, M.; Kanungo, M.; Sharma, S. Wheat responses and tolerance to UV-B radiation: An overview. In Wheat Pro-Duction in Changing Environments; Hasanuzzaman, M., Nahar, K., Hossain, M., Eds.; Springer: Singapore, 2019 ; pp. $175-196$. 
9. Almeselmani, M.; Deshmukh, P.S.; Sairam, R.K. High temperature stress tolerance in wheat genotypes: Role of antioxidant defence enzymes. Acta Agron. Hung. 2009, 57, 1-14. [CrossRef]

10. Kalhoro, N.A.; Rajpar, I.; Kalhoro, S.A.; Ali, A.; Raza, S.; Ahmed, M.; Kalhoro, F.A.; Ramzan, M.; Wahid, F. Effect of Salts Stress on the Growth and Yield of Wheat (Triticum aestivum L.). Am. J. Plant Sci. 2016, 7, 2257-2271. [CrossRef]

11. Cohen, I.; Rapaport, T.; Chalifa-Caspi, V.; Rachmilevitch, S. Synergistic effects of abiotic stresses in plants: A case study of nitrogen limitation and saturating light intensity in Arabidopsis thaliana. Physiol. Plant. 2018, 165, 755-767. [CrossRef] [PubMed]

12. Chojak-Koźniewska, J.; Kuźniak, E.; Zimny, J. The Effects of Combined Abiotic and Pathogen Stress in Plants: Insights from Salinity and Pseudomonas syringae pv lachrymans Interaction in Cucumber. Front. Plant Sci. 2018, 9, 1691. [CrossRef]

13. Stefanovic, L.; Zaric, L. Effect of herbicides and low temperatures on certain maize genotypes. Plant Protection 1991, 42, 345-356.

14. Sattar, A.; Sher, A.; Ijaz, M.; Ul-Allah, S.; Rizwan, M.S.; Hussain, M.; Jabran, K.; Cheema, M.A. Terminal drought and heat stress alter physiological and biochemical attributes in flag leaf of bread wheat. PLoS ONE 2020, 15, e0232974. [CrossRef]

15. Qaseem, M.F.; Qureshi, R.; Shaheen, H. Effects of Pre-Anthesis Drought, Heat and Their Combination on the Growth, Yield and Physiology of diverse Wheat (Triticum aestivum L.) Genotypes Varying in Sensitivity to Heat and drought stress. Sci. Rep. 2019, 9, 1-12. [CrossRef]

16. Cvikrová, M.; Gemperlová, L.; Martincová, O.; Vankova, R. Effect of drought and combined drought and heat stress on pol-yamine metabolism in proline-over-producing tobacco plants. Plant Physiol. Biochem. 2013, 73, 7-15. [CrossRef]

17. Shah, A.H.; Shah, S.H.; Ahmad, H.; Swati, Z.A.; Shah, A.H.; Afzal, M.; Aiman, U.; Khalid, Q. The phenomenon of cross tolerance in osmotically and ionically adapted rice (Oryza sativa L.) cell lines. Afr. J. Biotech. 2012, 11, 713-717.

18. Talanova, V.V.; Topchieva, L.V.; Titov, A.F. Effect of abscisic acid on the resistance of cucumber seedlings to combined exposure to high temperature and chloride. Biol. Bull. 2006, 33, 619-622. [CrossRef]

19. Doupis, G.; Chartzoulakis, K.; Beis, A.; Patakas, A. Allometric and biochemical responses of grapevines subjected to drought and enhanced ultraviolet-B radiation. Aust. J. Grape Wine Res. 2010, 17, 36-42. [CrossRef]

20. Sakalauskiene, S.; Šabajeviene, G.; Lazauskas, S.; Brazaityte, A.; Samuoliene, G.; Urbonavičiute, A.; Sakalauskaite, J.; Ulinskaite, R.; Duchovskis, P. Complex influence of different humidity and temperature regime on pea photosynthetic indices in VI-VII organogenesis stages. Sodinink. Darzinink. 2008, 27, 199-207.

21. Radyukina, N.L.; Toaima, V.I.M.; Zaripova, N.R. The involvement of low-molecular antioxidants in cross-adaptation of medicine plants to successive action of UV-B radiation and salinity. Russ. J. Plant Physiol. 2012, 59, 71-78. [CrossRef]

22. Juknys, R.; Račaitè, M.; Vitkauskaitè, G. Cross-adaptation of spring barley (Hordeum vulgare L.) to environmental stress induced by heavy metals. Ekologija 2010, 56, 1-9. [CrossRef]

23. McCarthy-Suárez, I. Role of reactive oxygen species in auxin herbicide phytotoxicity: Current information and hormonal im-plications-Are gibberellins, cytokinins, and polyamines involved? Botany 2017, 95, 369-385. [CrossRef]

24. Langaro, A.C.; Agostinetto, D.; Ruchel, Q.; Garcia, J.R.; Perboni, L.T. Oxidative stress caused by the use of preemergent herb-icides in rice crops. Rev. Ciênc. Agron. 2017, 48, 358-364. [CrossRef]

25. Peterson, M.A.; McMaster, S.A.; Riechers, D.E.; Skelton, J.; Stahlman, P.W. 2,4-D Past, Present, and Future: A Review. Weed Technol. 2016, 30, 303-345. [CrossRef]

26. Hasanuzzaman, M.; Bhuyan, M.H.M.B.; Parvin, K.; Bhuiyan, T.F.; Anee, T.I.; Nahar, K.; Hossen, S.; Zulfiqar, F.; Alam, M.; Fujita, M. Regulation of ROS Metabolism in Plants under Environmental Stress: A Review of Recent Experimental Evidence. Int. J. Mol. Sci. 2020, 21, 8695. [CrossRef] [PubMed]

27. Savvides, A.; Ali, S.; Tester, M.; Fotopoulos, V. Chemical Priming of Plants Against Multiple Abiotic Stresses: Mission Possible? Trends Plant Sci. 2016, 21, 329-340. [CrossRef] [PubMed]

28. Kulkarni, M.; Soolanayakanahally, R.; Ogawa, S.; Uga, Y.; Selvaraj, M.G.; Kagale, S. Drought Response in Wheat: Key Genes and Regulatory Mechanisms Controlling Root System Architecture and Transpiration Efficiency. Front. Chem. 2017, 5, 106. [CrossRef] [PubMed]

29. Simova-Stoilova, L.; Kirova, E.; Pecheva, D. Drought stress response in winter wheat varieties-changes in leaf proteins and proteolytic activities. Acta Bot. Croat. 2020, 79. [CrossRef]

30. Gao, H.; Wang, Y.; Xu, P.; Zhang, Z. Overexpression of a WRKY transcription factor TaWRKY2 enhances drought stress tol-erance in transgenic wheat. Front. Plant Sci. 2018, 9, 997. [CrossRef] [PubMed]

31. Kirova, E.; Pecheva, D.; Simova-Stoilova, L. Drought response in winter wheat: Protection from oxidative stress and mutagenesis effect. Acta Physiol. Plant. 2021, 43, 1-11. [CrossRef]

32. Kartseva, T.; Dobrikova, A.; Kocheva, K.; Alexandrov, V.; Georgiev, G.; Brestič, M.; Misheva, S. Optimal Nitrogen Supply Ameliorates the Performance of Wheat Seedlings under Osmotic Stress in Genotype-Specific Manner. Plants 2021, 10, 493. [CrossRef] [PubMed]

33. Abid, M.; Ali, S.; Qi, L.K.; Zahoor, R.; Tian, Z.; Jiang, D.; Snider, J.L.; Dai, T. Physiological and biochemical changes during drought and recovery periods at tillering and jointing stages in wheat (Triticum aestivum L.). Sci. Rep. 2018, 8, 1-15. [CrossRef]

34. Sallam, A.; Alqudah, A.M.; Dawood, M.F.A.; Baenziger, P.S.; Börner, A. Drought stress tolerance in wheat and barley: Ad-vances in physiology, breeding and genetics research. Int. J. Mol. Sci. 2019, 20, 3137. [CrossRef]

35. Xu, Z.; Zhou, G.; Shimizu, H. Plant responses to drought and rewatering. Plant Signal. Behav. 2010, 5, 649-654. [CrossRef] 
36. Marcińska, I.; Czyczyło-Mysza, I.; Skrzypek, E.; Filek, M.; Grzesiak, S.; Grzesiak, M.T.; Janowiak, F.; Hura, T.; Dziurka, M.; Dziurka, K.; et al. Impact of osmotic stress on physiological and biochemical characteristics in drought-susceptible and drought-resistant wheat genotypes. Acta Physiol. Plant. 2012, 35, 451-461. [CrossRef]

37. Schwachtje, J.; Whitcomb, S.J.; Firmino, A.A.P.; Zuther, E.; Hincha, D.K.; Kopka, J. Induced, Imprinted, and Primed Responses to Changing Environments: Does Metabolism Store and Process Information? Front. Plant Sci. 2019, 10, 106. [CrossRef]

38. Hamada, S.; Abdel-Lateef, M.; Abdelmonem, A.; El-Kholy, R.; Helalia, A. Efficiency of certain clodinafop-propargyl formulations in controlling annual grassy weeds in wheat. Ann. Agric. Sci. 2013, 58, 13-18. [CrossRef]

39. Guan, W.; Ma, Y.; Zhang, H. Dissipation of Clodinafop-Propargyl and Its Metabolite in Wheat Field Ecosystem. Bull. Environ. Contam. Toxicol. 2013, 90, 750-755. [CrossRef] [PubMed]

40. Lukatkin, A.S.; Gar'Kova, A.N.; Bochkarjova, A.S.; Nushtaeva, O.V.; da Silva, J.A.T. Treatment with the herbicide TOPIK induces oxidative stress in cereal leaves. Pestic. Biochem. Physiol. 2013, 105, 44-49. [CrossRef] [PubMed]

41. Hassannejad, S.; Ghafarbi, S.P. Assessment of some chlorophyll a fluorescence parameters of different corn cultivars in response to clodinafop-propagrgyl herbicide and salicylic acid. J. Plant Physiol. Breed. 2018, 8, 47-57.

42. Zobiole, L.; Gast, R.; Masters, R.; Pereira, G.; Rubin, R. Pyroxsulam: Sulfonamide Herbicide for Weed Control in Wheat in Brazil. Planta Daninha 2018, 36, 018155253. [CrossRef]

43. Zainulabdeen, J.A.; Ibrahim, S.A. Effect of herbicide pyroxsulam on nickel, cadmium, lead and total flavonoid levels of two Iraqi wheat. EurAsian J. BioSci. 2020, 14, 2817-2821.

44. Hossain, M.A.; Li, Z.-G.; Hoque, T.S.; Burritt, D.J.; Fujita, M.; Munné-Bosch, S. Heat or cold priming-induced cross-tolerance to abiotic stresses in plants: Key regulators and possible mechanisms. Protoplasma 2018, 255, 399-412. [CrossRef]

45. Carvalho, F.E.L.; Silveira, J.A.G. H2O2-retrograde signaling as a pivotal mechanism to understand priming and cross stress tolerance in plants. In Priming-Mediated Stress and Cross-Stress Tolerance in Crop Plants; Hossain, M.A., Liu, F., Burritt, D., Fujita, M., Huang, B., Eds.; Academic Press: Cambridge, MA, USA, 2020; pp. 57-78.

46. Niienments, U. Responses of forest trees to single and multiple environmental stresses from seedlings to mature plants: Past stress history, stress interactions, tolerance and acclimation. Forest Ecol. Manag. 2010, 260, 1623-1639. [CrossRef]

47. Wang, X.; Liu, F.-L.; Jiang, D. Priming: A promising strategy for crop production in response to future climate. J. Integr. Agric. 2017, 16, 2709-2716. [CrossRef]

48. Alagna, F.; Balestrini, R.; Chitarra, W.; Marsico, A.D.; Nerva, L. Getting ready with the priming: Innovative weapons against biotic and abiotic crop enemies in a global changing scenario. In Priming-Mediated Stress and Cross-Stress Tolerance in Crop Plants; Hossain, M.A., Liu, F., Burritt, D., Fujita, M., Huang, B., Eds.; Academic Press: Cambridge, MA, USA, 2020; pp. 35-56.

49. Llorens, E.; González-Hernández, A.I.; Scalschi, L.; Fernández-Crespo, E.; Camañes, G.; Vicedo, B.; García-Agustín, P. Priming mediated stress and cross-stress tolerance in plants: Concepts and opportunities. In Priming-Mediated Stress and Cross-Stress Tolerance in Crop Plants; Hossain, M.A., Liu, F., Burritt, D., Fujita, M., Huang, B., Eds.; Academic Press: Cambridge, MA, USA, 2020; pp. 1-20.

50. Shahbaz, M.; Masood, Y.; Perveen, S.; Ashraf, M. Is foliar-applied glycine betaine effective in mitigating the adverse effects of drought stress on wheat (Triticum aestivum L.)? J. Appl. Bot. Food Qual. 2011, 84, 192-199.

51. Tounekti, T.; Hernández, I.; Müller, M.; Khemira, H.; Munné-Bosch, S. Kinetin applications alleviate salt stress and improve the antioxidant composition of leaf extracts in Salvia officinalis. Plant Physiol. Biochem. 2011, 49, 1165-1176. [CrossRef] [PubMed]

52. Bates, L.S.; Waldren, R.P.; Teare, I.D. Rapid determination of free proline for water-stress studies. Plant Soil 1973, 39, $205-207$. [CrossRef]

53. Kramer, G.F.; Norman, H.A.; Krizek, D.T.; Mirecki, R.M. influence of UV-B radiation on polyamines, lipid peroxidation and membrane lipids in cucumber. Phytochemistry 1991, 30, 2101-2108. [CrossRef]

54. Alexieva, V.; Sergiev, I.; Mapelli, S.; Karanov, E. The effect of drought and ultraviolet radiation on growth and stress markers in pea and wheat. Plant Cell Environ. 2001, 24, 1337-1344. [CrossRef]

55. Swain, T.; Goldstein, L. Methods in Polyphenol Chemistry; Pridham, J.B., Ed.; Pergamon Press: Oxford, UK, $1964 ;$ pp. 131-146.

56. Ellman, G.L. Tissue sulfhydryl groups. Arch. Biochem. Biophys. 1959, 82, 70-77. [CrossRef]

57. Aebi, M. Catalase in vitro. Methods Enzymol. 1984, 105, 121-126.

58. Dias, I.; Costa, M. Efect of low salt concentration on nitrate reductase and peroxidase of sugar beet leaves. J. Exp. Bot. 1983, 34, 537-543. [CrossRef]

59. Beauchamp, C.; Fridovich, I. Superoxide dismutase. Improved assay and an assay applicable to acrylamide gels. Anal. Biochem. 1971, 44, 276-287. [CrossRef]

60. Smith, I.K.; Vierheller, T.L.; Thorne, C.A. Assay of glutathione reductase in crude tissue homogenates using 5, $5^{\prime}$-dithiobis(2nitrobenzoic acid). Anal. Biochem. 1988, 175, 408-413. [CrossRef]

61. Bradford, M. A rapid and sensitive method for the quantification of microgram quantities of protein utilizing the principle of protein-dye binding. Analyt. Biochem. 1976, 72, 248-254. [CrossRef] 